\title{
Effect of Zinc and Molybdenum on Growth, Yield Attributes, Yield and Protein in Grain on Summer Blackgram (Vigna mungo L.)
}

\author{
Chhatrapati Mahilane* and Vikram Singh
}

Department of Agronomy, Naini Agricultural Institute, Sam Higginbottom University of Agriculture, Technology and Sciences, Allahabad - 211007, Uttar Pradesh, India

*Corresponding author

\section{A B S T R A C T}

\begin{tabular}{|c|}
\hline Keywords \\
\hline $\begin{array}{l}\text { Blackgram, Zinc } \\
\text { and molybdenum }\end{array}$ \\
\hline Article Info \\
\hline $\begin{array}{l}\text { Accepted: } \\
\text { 10 December } 2017 \\
\text { Available Online: } \\
\text { 10 January } 2018\end{array}$ \\
\hline
\end{tabular}

A field experiment was conducted during the Zaid season 2016 at the Crop Research farm of Agronomy, Naini Agricultural Institute, SHUATS, Allahabad (U.P.) to Field evaluation of blackgram (Vigna mungo L.) under Agro-climatic zone of Allahabad. The experiment was conducted to find out the effect of different levels of zinc and molybdenum on growth and yield of blackgram (Vigna mungo L.) laid out in RBD with 9 treatment and 3 replications. The treatment consisted of three levels of zinc $\left(0,5\right.$ and $\left.7.5 \mathrm{~kg} \mathrm{ha}^{-1}\right)$, three levels of molybdenum $\left(0,0.5\right.$ and $\left.1.0 \mathrm{~kg} \mathrm{ha}^{-1}\right)$ treatment had significantly the highest plant height (29.29 and $30.51 \mathrm{~cm}$ at 45 and 60 DAS), number of branches (7.40 and 7.40 at 45 and 60 DAS), Crop growth rate $\left(0.30,0.85\right.$ and $4.91 \mathrm{~g} \mathrm{~m}^{-2}$ day $^{-1}$ at $0-15,15-30$ and 45-60 DAS) except at significantly higher value 1.35 at 30-45 DAS, protein content in grain $(24.70 \%)$ and grain yield $\left(1.18 \mathrm{t} \mathrm{ha}^{-1)}\right.$. However significantly higher straw yield $(4.14 \mathrm{t}$ $\left.\mathrm{ha}^{-1}\right)$ in $\left(\mathrm{T}_{6}\right)$ R.D.F + Zinc $5 \mathrm{~kg} \mathrm{ha}^{-1}+$ Molybdenum $1.0 \mathrm{~kg} \mathrm{ha}^{-1}$.

\section{Introduction}

Pulses have occupied immense significance in recent years as an important component of Indian economy. Pulses are seeds of leguminous plants and belong to the family Fabaceae. Pulses are rich source of protein and thus form an important part of vegetarian diet supplying the major portion of the protein requirements to human nourishment. About 88 per cent of protein consumed in India is of vegetable origin. Pulses are also rich in Vitamin B. Germinate seeds of pulses contain Vitamin C. Pulses have 2 to 6 per cent fats and can meet the essential fatty acids.
Pulse crops are unique in the sense that these possess capacity of fixing atmospheric nitrogen through nitrogen fixing bacteria found in their nodules and thus meet their own nitrogen requirements to a great extent. Pulses are fairly. Drought tolerant due to their deep root system and many of them are short duration crops. These are also ideal for intercropping as well as for multiple cropping system (Malik et al., 2015).

Productivity of pulses is low for these crops are mostly grown on marginal and submarginal soils with little or no application of fertilizers. Majority of pulse-growing regions 
of India are low in $\mathrm{Zn}$ content, and therefore, application of $1.5-5 \mathrm{~kg} \mathrm{Zn} / \mathrm{ha}$ alone or over and above the recommended doses of NPKS to different pulse crops are necessary. The application of $\mathrm{Zn}$ results in the enhancement of grain yield and quality. Genetic variability for response to applied $\mathrm{Zn}$ has been noticed among different cultivars of pulses. The $\mathrm{Zn}$ requirements of crops are low. $\mathrm{Zn}$ application may be performed once in a year, alternate years or after 3-5 years depending on $\mathrm{Zn}$ status of the soil. Several methods of $\mathrm{Zn}$ application viz., soil, seed coating, spraying, etc. have been found effective in correcting the $\mathrm{Zn}$ deficiency of the plants. Among different methods of application, soil application of $\mathrm{ZnSO} 4$ is most common and sometimes, it provides more beneficial results than other sources of $\mathrm{Zn}$ application. Soil application of $\mathrm{Zn}$ depends on nutrient status in soil, soil types, rainfall, organic matter addition and cropping systems. The $\mathrm{Zn}$ applied in one crop of the system generally takes care of the $\mathrm{Zn}$ requirements of the succeeding crop too. Singh et al., (2011)

Deficiency of $\mathrm{Zn}$ in the soil leads to the dietary malnutrition and health problems in human and animals. Presently half of the world population is affected with $\mathrm{Zn}$ deficiency (Cakmak, 2008a; Cakmak, 2008b and Takkar et al., 1989), and therefore, it comes second only after iron. In India, about $25 \%$ of the population is suffering from $\mathrm{Zn}$ related problems and nearly half of the Indian children under the age of 5 are small due to the Zn deficiency Singh et al., (2009). Zn deficiency is also known to cause several diseases like hypogonadism, anorexia, dwarfism, skin lesion, geophagia, loss of taste, skin lesion, and the like. The $\mathrm{Zn}$ related problems are more acute in woman of child bearing age and younger generations including children and livestock. The crops grown in $\mathrm{Zn}$ deficient soils are generally having lower zinc content (consequently lower $\mathrm{Zn}$ uptake) and intake of produce of such crops or crops as such leads to health related problems in the humans and animals.

Molybdenum is one of the most recognized nutrient elements considered to be essential for the growth of plant. Food insecurity in the $21^{\text {st }}$ century will even increase due to heat and drought stress induced by the climate change, particularly in tropical and subtropical regions. Legumes are good and relatively cheaper source of proteins, carbohydrates and minerals for developing countries including India.

\section{Materials and Methods}

In order to study the Influence of the experiment of urdbean (Vigna mungo L.) in relation to zinc and molybdenum a field experiment was carried out at in year 2016 during summer season at Crop Research Farm (CRF), Naini Agricultural Institute, Department of Agronomy, Sam Higginbottom University of Agriculture, Technology and Sciences, Allahabad. Treatment combinations comprised with three levels of zinc viz., $0 \mathrm{~kg}$, $5 \mathrm{~kg}, 7.5 \mathrm{~kg}$ and $7.5 \mathrm{~kg} \mathrm{ha}^{-1}$ and three levels of molybdenum viz., $0 \mathrm{~kg}, 0.5 \mathrm{~kg}$ and $1.0 \mathrm{~kg} \mathrm{ha}^{-1}$ with recommended dose of NPK kg ha ${ }^{-1}$. Nine treatments combinations were replicated three times in randomized block design.

The soil of the experimental field was sandy loam in texture, slightly alkaline in reaction ( $\mathrm{pH} 7.60)$ with low level of organic carbon $00.34 \%$, available medium level of $P(13.5 \mathrm{~kg}$ $\left.\mathrm{ha}^{-1}\right)$ and higher level of $\mathrm{K}\left(336 \mathrm{~kg} \mathrm{ha}^{-1}\right)$. Total and available $\mathrm{N}$ was analysed by Subbiah and Asija, 1956, Zinc by DTPA extractants Dithizonate method and Mo by using water and ammonium oxalate extractants (Jackson, 1973). The value of table ' $F$ at $5 \%$ level significance, where the treatment difference between were found significant the value of $\mathrm{CD}$ and $\mathrm{CV} \%$ were also worked out to compare the treatment mean (Snedecor and 
Cochran 1967). At initial stage select random five plants from net plot area for further recording observations.

\section{Results and Discussion}

\section{Effect of growth parameters on blackgram}

The data present indicated that in Table 1 indicates the plant height at 45 DAS significantly the highest in treatment $\left(\mathrm{T}_{9}\right)$ : R.D.F+ Zinc $7.5 \mathrm{~kg} \mathrm{ha}^{-1}+$ Molybdenum $1.0 \mathrm{~kg}$ $\mathrm{ha}^{-1}$ with $29.29 \mathrm{~cm}$ and at 60 DAS, significantly the highest value of plant height $(30.51 \mathrm{~cm})$ in treatment $\left(\mathrm{T}_{9}\right)$ R.D.F+ Zinc 7.5 $\mathrm{kg} \mathrm{ha}^{-1}+$ Molybdenum $1.0 \mathrm{~kg} \mathrm{ha}^{-1}$.

The increase in plant height under zinc treatment may be due to its effect in the metabolism of growing plants, which may effectively explain the observed response of zinc application. Favourable response of zinc application on plant height has also been reported by Shanti, et al., 2008.

The increase in growth attributes due to molybdenum might be due to that molybdenum is a structural component of nitrogenase and the enzyme actively involved in nitrogen fixation by root nodule bacteria of leguminous crops. Similar findings were also reported by Kumar and Sharma (2005) and Khan and Prakash (2013)

Crop growth rate significantly the highest at (0-15, 15-30, 45-60 DAS) was observed value (0.30, 0.85 and $4.91 \mathrm{~g} \mathrm{~m}^{-2} \mathrm{day}^{-1}$ in treatment $\left(\mathrm{T}_{9}\right)$ R.D.F+ Zinc $7.5 \mathrm{~kg} \mathrm{ha}^{-1}+$ Molybdenum $1.0 \mathrm{~kg} \mathrm{ha}^{-1}$ respectively. While significantly higher as same treatment crop growth rate value was observed $\left(1.35 \mathrm{~g} \mathrm{~m}^{-2}\right.$ day $^{-1}$ at $30-45$ DAS).

With the respect significantly the highest number of branches both intervals at 45 and 60 DAS was observed value same as $(7.40$ plant $\left.^{-1}\right)$ in treatment $\left(\mathrm{T}_{9}\right)$ R.D.F + Zinc $7.5 \mathrm{~kg}$ $\mathrm{ha}^{-1}+$ Molybdenum $1.0 \mathrm{~kg} \mathrm{ha}^{-1}$ respectively.

\section{Yields attributes and yield of blackgram}

The data pertaining to effect of different levels of zinc and molybdenum on grain yield. Significantly the highest grain yield $(1.18 \mathrm{t}$ $\left.\mathrm{ha}^{-1}\right)$, was observed under treatment $\left(\mathrm{T}_{9}\right)$ R.D.F + Zinc $7.5 \mathrm{~kg} \mathrm{ha}^{-1}+$ Molybdenum 1.0 $\mathrm{kg} \mathrm{ha}^{-1}$, whereas, significantly the lowest grain yield $\left(1.18 \mathrm{t} \mathrm{ha}^{-1}\right)$, was observed under treatment $\mathrm{T}_{1}$ R.D.F + Zinc $00 \mathrm{~kg} \mathrm{ha}^{-1}+$ Molybdenum 00kg ha ${ }^{-1}$ and $\mathrm{T}_{4}$ R.D.F + Zinc 5 $\mathrm{kg} \mathrm{ha}{ }^{-1}+$ Molybdenum $00 \mathrm{~kg} \mathrm{ha}{ }^{-1}$, respectively.

The data presented in Table 2 on grains per pod (5) was observed non significantly effect in treatment $\left(\mathrm{T}_{9}\right)$ R.D.F + Zinc $7.5 \mathrm{~kg} \mathrm{ha}^{-1}+$ Molybdenum $1.0 \mathrm{~kg} \mathrm{ha}^{-1}, \mathrm{~T}_{3}$ R.D.F + Zinc 00 $\mathrm{kg} \mathrm{ha}^{-1}+$ Molybdenum $1.0 \mathrm{~kg} \mathrm{ha}^{-1}$ and $\mathrm{T}_{8}$ R.D.F+ Zinc $7.5 \mathrm{~kg} \mathrm{ha}^{-1}+$ Molybdenum 0.5 $\mathrm{kg} \mathrm{ha}^{-1}$, respectively.

The increased in yield might be due to positive effect of zinc on yield attributes as it plays an important role in metabolic process (Shanti et al., 2008 and Ahmed et al., 2013).

The increase in seed and haulm yield of blackgram due to zinc might be attributed to the reason that, zinc shows beneficial effects on chlorophyll content and so it indirectly influences the photosynthesis and reproduction.

The channelization of photosynthates during reproductive stage might have been influenced by zinc, by way of its involvement in electron transport (Baker et al., 1982).

Sudharsan and Ramaswami (1993) found that residual effect of $\mathrm{ZnSO}_{4}$ gave good seed and haulm yield in blackgram crop in a groundnutblackgram cropping system Shanti et al., (2008). 
Table.1 Response of different levels of zinc and molybdenum on growth attributes of blackgram (Vigna mungo L.)

\begin{tabular}{|c|c|c|c|c|c|c|c|c|}
\hline \multirow[t]{2}{*}{ Treatment combinations } & \multicolumn{2}{|c|}{ Plant height (cm) } & \multicolumn{4}{|c|}{ Crop growth rate $\left(\mathrm{g} \mathrm{m}^{-2} \mathrm{day}^{-1}\right)$} & \multicolumn{2}{|c|}{$\begin{array}{c}\text { Number of } \\
\text { branches } \\
\text { plant }^{-1}\end{array}$} \\
\hline & 45 DAS & $\begin{array}{c}60 \\
\text { DAS }\end{array}$ & $\begin{array}{l}0-15 \\
\text { DAS }\end{array}$ & $\begin{array}{l}15-30 \\
\text { DAS }\end{array}$ & $\begin{array}{l}30-45 \\
\text { DAS }\end{array}$ & $\begin{array}{l}45-60 \\
\text { DAS }\end{array}$ & $\begin{array}{c}45 \\
\text { DAS }\end{array}$ & $\begin{array}{c}60 \\
\text { DAS }\end{array}$ \\
\hline $\begin{array}{l}\text { T }: \text { R.D.F + Zinc } 00 \mathrm{~kg} \mathrm{ha}^{-1}+\text { Molybdenum } \\
\text { 00kg ha- }\end{array}$ & 26.19 & 26.64 & 0.27 & 0.34 & 0.93 & 4.45 & 4.53 & 4.53 \\
\hline $\begin{array}{l}\mathrm{T}_{2}: \text { R.D.F + Zinc } 00 \mathrm{~kg} \mathrm{ha}^{-1}+\text { Molybdenum } \\
0.5 \mathrm{~kg} \mathrm{ha}^{-1}\end{array}$ & 26.89 & 27.29 & 0.27 & 0.41 & 1.21 & 4.32 & 5.73 & 5.73 \\
\hline $\begin{array}{l}\mathrm{T}_{3}: \text { R.D.F }+ \text { Zinc } 00 \mathrm{~kg} \mathrm{ha}^{-1}+\text { Molybdenum } \\
1.0 \mathrm{~kg} \mathrm{ha}^{-1}\end{array}$ & 27.65 & 28.23 & 0.27 & 0.69 & 1.13 & 4.72 & 6.80 & 6.80 \\
\hline $\begin{array}{l}\mathrm{T}_{4}: \text { R.D.F }+ \text { Zinc } 5 \mathrm{~kg} \mathrm{ha}^{-1}+\text { Molybdenum } \\
00 \mathrm{~kg} \mathrm{ha}^{-1}\end{array}$ & 27.44 & 28.15 & 0.27 & 0.61 & 0.98 & 4.32 & 5.47 & 5.47 \\
\hline $\begin{array}{l}\text { T }_{5}: \text { R.D.F }+ \text { Zinc } 5 \mathrm{~kg} \mathrm{ha}^{-1}+\text { Molybdenum } \\
0.5 \mathrm{~kg} \mathrm{ha}^{-1}\end{array}$ & 28.03 & 28.59 & 0.28 & 0.70 & 1.05 & 4.36 & 6.60 & 6.60 \\
\hline $\begin{array}{l}\text { T6 }: \text { R.D.F + Zinc } 5 \mathrm{~kg} \mathrm{ha}^{-1}+\text { Molybdenum } \\
\text { 1.0kg ha }\end{array}$ & 28.51 & 29.22 & 0.28 & 0.78 & 1.20 & 4.78 & 7.00 & 7.00 \\
\hline $\begin{array}{l}\text { T }_{7}: \text { R.D.F }+ \text { Zinc } 7.5 \mathrm{~kg} \mathrm{ha}^{-1}+\text { Molybdenum } \\
00 \mathrm{~kg} \mathrm{ha}^{-1}\end{array}$ & 28.45 & 29.39 & 0.28 & 0.78 & 0.98 & 4.30 & 6.20 & 6.20 \\
\hline $\begin{array}{l}\text { T8 }: \text { R.D.F+ Zinc } 7.5 \mathrm{~kg} \mathrm{ha}^{-1}+\text { Molybdenum } \\
0.5 \mathrm{~kg} \mathrm{ha}^{-1}\end{array}$ & 28.94 & 29.87 & 0.28 & 0.79 & 1.02 & 4.82 & 6.80 & 6.80 \\
\hline $\begin{array}{l}\text { T9: R.D.F+ Zinc7.5 } \mathrm{kg} \mathrm{ha}^{-1}+\text { Molybdenum } \\
1.0 \mathrm{~kg} \mathrm{ha}^{-1}\end{array}$ & 29.29 & 30.51 & 0.30 & 0.85 & 1.35 & 4.91 & 7.40 & 7.40 \\
\hline F test & S & $\mathrm{S}$ & S & $\mathrm{S}$ & $\mathrm{S}$ & $\mathrm{S}$ & S & $\mathrm{S}$ \\
\hline SEd(_+) & 0.03 & 0.13 & 0.001 & 0.01 & 0.01 & 0.04 & 0.09 & 0.09 \\
\hline $\mathrm{CD}(\mathrm{P}=0.05)$ & 0.07 & 0.27 & 0.01 & 0.03 & 0.45 & 0.08 & 0.19 & 0.19 \\
\hline
\end{tabular}


Table.2 Response of different levels of zinc and molybdenum on yield attributes, yield and protein content in grain of blackgram (Vigna mungo L.)

\begin{tabular}{|c|c|c|c|c|c|}
\hline Treatment combinations & $\begin{array}{l}\text { Grains per } \\
\text { pod (No.) }\end{array}$ & $\begin{array}{l}\text { Grain yield t } \\
\text { ha }^{-1}\end{array}$ & $\begin{array}{l}\text { Straw yield t } \\
\text { ha }^{-1}\end{array}$ & $\begin{array}{l}\text { Biological } \\
\text { yield } \mathrm{tha}^{-1}\end{array}$ & $\begin{array}{l}\text { Protein Content } \\
\text { in grain }(\%)\end{array}$ \\
\hline $\begin{array}{l}\mathrm{T}_{1}: \text { R.D.F }+ \text { Zinc } 00 \mathrm{~kg} \mathrm{ha}^{-1}+\text { Molybdenum } \\
00 \mathrm{~kg} \mathrm{ha}^{-1}\end{array}$ & 4.60 & 1.01 & 3.71 & 4.73 & 23.80 \\
\hline $\begin{array}{l}\mathrm{T}_{2}: \text { R.D.F }+ \text { Zinc } 00 \mathrm{~kg} \mathrm{ha}^{-1}+\text { Molybdenum } \\
0.5 \mathrm{~kg} \mathrm{ha}^{-1}\end{array}$ & 4.80 & 1.10 & 3.80 & 4.90 & 23.90 \\
\hline $\begin{array}{l}\mathrm{T}_{3}: \text { R.D.F }+ \text { Zinc } 00 \mathrm{~kg} \mathrm{ha}^{-1}+\text { Molybdenum } 1.0 \\
\mathrm{~kg} \mathrm{ha}^{-1}\end{array}$ & 5.00 & 1.15 & 3.81 & 4.96 & 23.80 \\
\hline $\begin{array}{l}\mathrm{T}_{4}: \text { R.D.F }+ \text { Zinc } 5 \mathrm{~kg} \mathrm{ha}^{-1}+\text { Molybdenum } 00 \\
\mathrm{~kg} \mathrm{ha}^{-1}\end{array}$ & 4.80 & 1.08 & 3.71 & 4.80 & 24.40 \\
\hline $\begin{array}{l}\mathrm{T}_{5}: \text { R.D.F+ Zinc } 5 \mathrm{~kg} \mathrm{ha}^{-1}+\text { Molybdenum } 0.5 \\
\mathrm{~kg} \mathrm{ha}^{-1}\end{array}$ & 4.80 & 1.11 & 3.96 & 5.08 & 24.40 \\
\hline $\begin{array}{l}\mathrm{T}_{6}: \text { R.D.F }+ \text { Zinc } 5 \mathrm{~kg} \mathrm{ha}^{-1}+\text { Molybdenum } \\
1.0 \mathrm{~kg} \mathrm{ha}^{-1}\end{array}$ & 5.00 & 1.17 & 4.14 & 5.31 & 24.30 \\
\hline $\begin{array}{l}\mathrm{T}_{7}: \text { R.D.F+ Zinc } 7.5 \mathrm{~kg} \mathrm{ha}^{-1}+\text { Molybdenum } 00 \\
\mathrm{~kg} \mathrm{ha}^{-1}\end{array}$ & 4.80 & 1.09 & 3.87 & 4.97 & 24.70 \\
\hline $\begin{array}{l}\text { T } \text { : R.D.F+ Zinc } 7.5 \mathrm{~kg} \mathrm{ha}^{-1}+\text { Molybdenum } 0.5 \\
\mathrm{~kg} \mathrm{ha}^{-1}\end{array}$ & 5.00 & 1.13 & 3.84 & 4.96 & 24.60 \\
\hline $\begin{array}{l}\mathrm{T}_{9}: \text { R.D.F+ Zinc } 7.5 \mathrm{~kg} \mathrm{ha}^{-1}+\text { Molybdenum } 1.0 \\
\mathrm{~kg} \mathrm{ha}^{-1}\end{array}$ & 5.00 & 1.18 & 3.84 & 5.02 & 24.70 \\
\hline F test & NS & $\mathrm{S}$ & $\mathrm{S}$ & $\mathrm{S}$ & $\mathrm{S}$ \\
\hline $\operatorname{SEd}(++)$ & 0.18 & 0.003 & 0.01 & 0.02 & 0.10 \\
\hline $\mathrm{CD}(\mathrm{P}=0.05)$ & 0.39 & 0.010 & 0.03 & 0.04 & 0.21 \\
\hline
\end{tabular}


This increase was due to the reason that blackgram being a legume crop, fixes the atmospheric nitrogen in the soil. These results corroborate the findings of the Tomar et al., (1996) in groundnut. Almost similar trend was observed in case of no zinc control. In absolute control there was slight decrease of $\mathrm{N}$ at harvest of blackgram (Shanti et al., 2008).

This might be due to the fact that molybdenum is helpful in formation of nodules. Similar results were also reported by Singh et al., (2006) and Bhuiyan et al., (2008) and Khan and Prakash (2013)

The increase in yield may be due to increase in the availability of this nutrient with the application of this content (Sharma and Abraham 2010).

\section{Quality parameters of blackgram}

Effect of different levels of zinc and molybdenum on protein content in grain (\%), revealed significant effect on oil content (\%). Significantly the highest protein content $(24.70 \%)$ was recorded under treatment $\mathrm{T}_{9}$ ) R.D.F + Zinc $7.5 \mathrm{~kg} \mathrm{ha}^{-1}+$ Molybdenum 1.0 $\mathrm{kg} \mathrm{ha}^{-1}$ and $\mathrm{T}_{7}$ R.D.F+ Zinc $7.5 \mathrm{~kg} \mathrm{ha}^{-1}+$ Molybdenum $00 \mathrm{~kg} \mathrm{ha}^{-1}$ respectively.

The minimum seed protein content of urdbean was recorded in without zinc application. The increase in seed protein content in grain of urd bean with the application of zinc have also been reported by Krishna (1995) and Singh and Yadav (1997).

The minimum protein contet in grain was recorded in without molybdenum applied plots. The role of molybdenum is well established in improving the quality by nitrogenase enzyme which is helpful in protein synthesis. These results are in agreement with the findings of Jat and
Rathore, 1994. It is concluded that $\mathrm{T}_{9}$ (R.D.F + Zinc7.5 $\mathrm{kg} \mathrm{ha}^{-1}+$ Molybdenum1.0 $\mathrm{kg} \mathrm{ha}^{-1}$.) was best for obtaining maximum growth attributes, yield attributes, yield and protein content in grain of Blackgram. Since the findings were based on the research done in one season it may be repeated for further confirmation.

\section{References}

Ahmed I, Akhtar M.J, Asgar H.N and Khalid M. 2013. Influence of Rhizobium applied in combination with micronutrient on mungbean. Pakistan Journal of Life Sciences, X(X): XXX.

Baker, N. R., et al., 1982. Physiol. Plantarum, 56: $217-222$.

Bhuiyan M.M.H, Rahman M.M, Afroz F, Sutradhar G.N.C and Bhuiyan M.S.I. 2008. Effect of phosphorus, molybdenum and Rhizobium inoculation on growth and nodulation of mungbean. Journal of Soil Nature 2: 25-30.

Cakmak, I. FAI annual Seminar 2008a, New Delhi, SII-2pp. 1-8 2008.

Cakmak, I. Plant Soil 302: 1-17 2008b.

Jackson ML. 1973. Soil Chemical Analysis. Prentice Hall of India Pvt. Ltd, New Delhi.

Jat RL and Rathore PS. 1994. Effect of S, Mo and Rhizobium inoculation on green gram (Phaseolus radiatus). Indian Journal of Agronomy 39: 651-654.

Khan Khalil and Prakash Ved. 2013. Response of summer urdbean (Vigna mungo L.) to zinc, molybdenum and Rhizobium., Current Advances in Agricultural Sciences 5(2): 205-208

Krishna 1995. Effect of sulphur and zinc application on yield, $\mathrm{S}$ and $\mathrm{Zn}$ uptake and protein content of mung. Legume Research 8: 89-92.

Kumar J and Sharma M, 2005. Effect of phosphorus and molybdenum on yield 
and nutrient uptake by chickea (Cicer arietinum L). Advances in Plant Science 18: 869-873

Malik, Kusum Kumar Satish and Singharya K.P. 2015. Effect of zinc, molybdenum and urea on chlorophyll and protein content of mungbean (Vigna radiata $\mathrm{L}$. Wilczek). International Journal of Plant Sciences 10 (2) 152-157

Shanti M, Babu BP, Prasad BR and Minhas PS. 2008. Effect of zinc on blackgram in rice-blackgram cropping system of coastal saline soils. Legume Research 31: 79-86.

Sharma Vishal and Abraham Thomas 2010. Response of blackgram (phaseolus mungo) to nitrogen, zinc and farmyard manure, Legume Res., 33 (4): 295 - 298,

Singh RP, Singh RK, Yadav PK, Singh SN, Prasad L and Singh J. 2006. Effect of sulphur and molybdenum on yield and quality of blackgram (Vigna mungo L.). Crop Research 32: 336-338.
Singh U and Yadav DS. 1997. Study on sulphur and zinc nutrition of green gram (Phaseolus radiatus L) in relation to growth attributes, seed protein, yield and $\mathrm{S}$ and $\mathrm{Zn}$ uptake. Legume Research 20: 224- 226.

Singh, A.P., J. Indian Soc. Soil Sci. 58 (1):41522009.

Snedecor, G.W. and Cochran, W.G. 1967. "Statistical method". The IOWA state University Press, IOWA

Subbiah BV and Asija GL. 1956. A rapid procedure for the determination of available nitrogen in soils. Current Science, 25:259-260.

Sudharsan, S., and Ramaswami, P. P. 1993. Fertilizer News, 38: 51-57.

Takkar, P.N., Chibba, I.M. and Mehta, S.K. 1989. Bulletin 1. Indian Institute of Soil Science, Bhopal, India (1967-1987).

Tomar, R. A. S., et al., 1996. Agric. Sci. Digest, 16: 83-86.

\section{How to cite this article:}

Chhatrapati Mahilane and Vikram Singh. 2018. Effect of Zinc and Molybdenum on Growth, Yield Attributes, Yield and Protein in Grain on Summer Blackgram (Vigna mungo L.). Int.J.Curr.Microbiol.App.Sci. 7(01): 1156-1162. doi: https://doi.org/10.20546/ijcmas.2018.701.140 